\title{
Implementation of Children's Numerical Skill Learning Activity in Early Childhood Education
}

\author{
Dadan Suryana $^{1}$ and Eva Delfia ${ }^{2}$ \\ ${ }^{1}$ Early Childhood Education Department, Padang State University, Padang, Indonesia, \\ dadan.suryana@yahoo.com \\ ${ }^{2}$ Early Childhood Education Department, Padang State University, Padang, Indonesia, \\ eva.delfiapgpaud2013@yahoo.com
}

\begin{abstract}
The purpose of this study was to determine the process of implementing numeracy skills learning activities in Aisyiyah 27 Bungo Pasang Padang Kindergarten. This research is a type of descriptive research with a qualitative approach. The subjects of this study were educators in the Aisyiyah 27 Bungo Pasang Padang Kindergarten, while the object of this study was the process of implementing numeracy skills. Data obtained through the results of observations and interviews and documentation. Data analysis techniques using triangulation techniques, namely by comparing the results of information that has been obtained, namely comparing the data from observations, observations with interview data and documentation. Data obtained by interviews, then checked by observation and documentation. The results of the data analysis state that the process of carrying out numeracy skills learning in Aisyiyah 27 Bungo Pasang Padang Kindergarten uses a variety of methods and media, namely using conversation, question and answer, and assignment methods. The media used are visual and audio visual media. It can be concluded that the planning, methods, implementation and assessment of the use of instructional media in numeracy skills in Aisyiyah 27 Bungo Pasang Padang Kindergarten are in accordance with the references.
\end{abstract}

Keywords: Implementation of learning, Numerical skills

\section{INTRODUCTION}

Early age is a very important age for the development of children so called the golden age. This period is a period of formation of brain tissue and psychological and emotional growth of children, so that the growth and development of children is good and goes according to their age maturity, do not let this golden period pass without any stimulation and stimulus that is appropriate for the child's development and development.

Early Childhood Education is one of the priority programs of national education development at the moment both in the form of formal, non-formal, and informal. The government through the Ministry of National Education strives to promote early childhood education in various regions, this government effort aims to give more attention to early childhood as the next generation that will advance the nation and the State. Therefore, early age is a very brilliant period for education.

Specifically, the purpose of kindergarten education is to help students develop both psychological and physical potential which includes religious, moral, social emotional, cognitive, language, and physical motoric values, to be ready to enter primary education. From the goals of kindergarten education, it can be seen that cognitive ability is one of the potentials that must be developed in students.

Cognitive ability plays an important role in children's development. This is because cognitive is closely related to thought processes. Individuals think using their mind, this ability that determines the speed or failure of a problem at hand. The cognitive development as referred to in paragraph 1 of the Minister of Education Regulation No. 137 of 2014 includes, (1) learning and problem solving, including the ability to solve simple problems in daily life in a flexible and socially acceptable way and applying knowledge or experience in a new context, (2) logical thinking, including various differences, classification, pattern, initiative, plan, and recognize cause and effect, (3) symbolic thinking, includes the ability to recognize, mention and use the concept of numbers, recognize letters and be able to present various objects and their imagination in the form of images.

According to Suryana (2018: 39) cognitive is the process of the results of assimilation, accommodation, and equilibrium. Assimilation is related to the process of absorbing new information into the information that already exists in the scheme (cognitive structure), the accommodation process brings together new information with information that already exists in the scheme so that the combination of information extends the child's schema, 
equilibrium related to the child's efforts to deal with the conflict in him when facing a problem.

Eliason and Jenkins (2008) state that cognitive development, language, and literacy can form thinking skills and build understanding. All aspects of development above must get maximum and optimal stimulation through meaningful learning activities for children involving parents, teachers and schools. knowledge of learning strategies, attitudes, and teacher motivation (Suryana: 2013).

Children's cognitive abilities in kindergarten aim to develop children's thinking skills in order to be able to manage learning acquisition, can find various kinds of alternatives to help children to develop children's numeracy skills. Cognitive development is needed by children in order to develop their knowledge. One of the cognitive abilities developed is numeracy. Ability to count is the ability to use reasoning, logic, and numbers to help children to think logically and have the power of intelligent thinking. One of the cognitive abilities developed is numeracy. Counting is the ability to use reasoning, logic, numbers to help children to think logically and have the power of intelligent thinking.

Counting is an ability that needs to be developed early with a variety of interesting media, the right method, because in a child's life cannot be separated from counting. If the child is introduced to counting in a fun way this is very valuable for the child so that in the future the child will be happy by learning to count and count it by introducing the child directly to the object around it so that the child calculates the real thing that is seen directly by the child.

To achieve the goal of numeracy in children, professional educators or teachers are needed. Professional teachers are teachers who have the skills, knowledge and creative ideas in using and designing game tools that are attractive to children. The role of the teacher is very important in developing children's numeracy skills. To develop numeracy skills, kindergarten children can be directed through various forms of activities or media used by teachers so that the implementation of activities in developing children's numeracy skills becomes more attractive.

Early childhood in general are able to count in a simple way, but to count to a higher level children are still experiencing difficulties such as the number tens. One of the problems related to counting in early childhood is the ability of children to recognize numbers with the number of objects. Children must recognize the concept of numbers based on the number of objects that the child will count.

In general, counting activities in early childhood aim to make children learn the basics of learning to count, so that later on the child will be better prepared to take part in more complex mathematics learning at the next level. In particular, playing mathematics in early childhood education aims to make children: able to think logically and systematically early, through observing concrete objects, pictures or images around children; Can adapt and involve themselves in people's lives which in daily life requires mathematical skills; Have high accuracy, concentration, abstraction and appreciation; Have an understanding of the concepts of space and time and can estimate the possible sequence of events that occur around them; Having creativity and imagination in creating things spontaneously. (Lee, 2011).

To achieve the goal of numeracy in children, professional educators or teachers are needed. Professional teachers are teachers who have the skills, knowledge and creative ideas in using and designing game tools that are attractive to children. The role of the teacher is very important in developing children's numeracy skills. To develop numeracy skills, kindergarten children can be directed through various forms of activities or media used by teachers so that the implementation of activities in developing children's numeracy skills becomes more attractive. Susanto (2011: 107) said that the factors that affect children's numeracy are: 1) Health factors, with good and healthy physical and psychological health the child will receive the given learning; 2) Environmental factors, human development is very much determined by its environment, intelligence is very much determined by the experience and knowledge gained from its environment; 3) Game factors, the game is very important because with the game children will quickly understand the purpose of the learning; 4) Factors of socio-economic status, this factor has a huge effect, because this involves the child's confidence in socializing with their environment.

In developing numeracy skills for children, teachers must be able to create various types of learning media that are interesting for children so that the motivated children for learning specifically learn to count. In addition, using media is accompanied by varied activities in early childhood learning so that children do not feel bored and do not feel bored in the learning process.

Learning media is a tool that can be used to convey messages to children so that the message delivered can be received by the child. Media is a very important thing in learning because besides the media is everything that functions as an intermediary or tool in learning, the media is also a component in the child's environment that can stimulate the development of children to learn, one of them is the child's numeracy.

According to Kustandi (2011: 25) the purpose of using media is: 1) learning media can clarify the presentation of messages and information, 2) learning media can improve and direct children's attention, 3) learning media can overcome sensory limitations, space, and time, 4) learning media can provide similar experiences to children.

The introduction of numbers given to children aims so that a child can better understand the concept of counting and can apply it in the surrounding environment or in daily life so that the developmental aspects of child counting can develop well. In developing numeracy skills in children can use a variety of media such as being able to use numeric cards, number blocks, animated videos, framed picture cards, number balls.

The media used by teachers should be varied in order to attract the interest of children in the learning process. 
Seen in the process of learning to count in some kindergartens, the media used by teachers does not vary, it is very influential on children's cognitive development, namely children's numeracy. Teachers should be able to develop creative ideas to provide varied media and activities in introducing numeracy. Many found in the field of teachers have not been able to vary the media for the introduction of numeracy in children, the media used are watching and the absence of renewal of the media used so that children are less interested in counting activities so that it can cause problems in children's numeracy skills.

Early childhood learning must be able to provide opportunities for children to get a scientific learning process. This will have an impact on children's thinking and insight when they continue their education to a higher level. The scientific process that can be done is the scientific approach. The process of children in gaining knowledge through the process of observing, asking, trying, reasoning and communicating.

\section{METHOD}

The research was conducted at Aisyiyah 27 Bungo Pasang Padang Kindergarten, located at Jl. Raya Lubuk Minturun Koto Tangah Padang. Time of implementation in 2018 school year.

This type of research is descriptive research with a qualitative approach. Descriptive method is a method in examining the status of a human group, an object, a condition, a system of thought or a class of events in the present that aims to describe or painting systematically, factually, and accurately about facts, traits and relationships between the phenomena investigated. According to Moleong (2012: 6) in a descriptive study the data collected in the study were in the form of words, images and not numbers.

The subjects in this study included the Bungo Pasang Padang Aisyiyah 27 Kindergarten School Principal who knew the history and background of the establishment of Aisyiyah 27 Bungo Pasang Padang Kindergarten, then the educator or teacher who became the facilitator in implementing learning. While the object of this research is the implementation of numeracy skills learning activities carried out in Aisyiyah 27 Bungo Pasang Padang Kindergarten.

To obtain data in this study, of course there is a need for data collection techniques, namely by observation and interviews. From several kinds of observations according to Sugiyono (2009: 310), including participatory observation, frank observation or disguised, and unstructured observation. The researcher uses a form of participatory observation, where the researcher makes observations directly so that the researcher gets information clearly and to know the realistic picture of behavior or events that occur when the learning takes place in school.

Another data collection technique is interview. In this study, in-depth interviews were used, where the researcher delved into information in depth by being directly involved in the way directly involved with the life of the informant and asking questions using guidelines prepared in advance so that the interview was directed and could be done many times. The last data collection technique is documentation.

The technique of validating the data used in this study is triangulation. Moleong (2012: 330) says triangulation is a technique of checking the validity of data that uses something else outside the data, for the purposes of checking or as a comparison to that data. The triangulation technique carried out in this study was triangulation with sources. In this case, the researcher compares the results of the information that has been obtained, namely comparing data from observations or observations with data from interviews and documentation. Data obtained by interviews, and then checked by observation and documentation.

\section{RESULTS}

A. Implementation Design of Children's Numerical Skill Thought Learning Activity

Based on the results of observations and interviews conducted by researchers, the planning of the implementation of activities in B2 class Aisyiyah 27 TK Bungo Pasang Padang, was arranged based on the existing curriculum. The first thing the teacher does is make a semester program. The semester program is grouped according to the theme that will be used during the first semester and second semester which is designed at the beginning of the year.

Then the Weekly Learning Implementation Plan (RPPM) is prepared based on the semester program that has been previously designed. Then from RPPM, the teacher prepares RPPH every day. The RPPH that will be delivered consists of playing environment, footing before playing, and footing after playing, resting and final activities.

\section{B. Learning Method of Numerical Skill}

Based on the results of observations and interviews conducted by researchers, the method of learning numeracy in class B2 of Aisyiyah 27 Bungo Pasang Padang Kindergarten, using the method of questioning, conversation, and the method of giving assignments. The use of learning methods is adapted to the media and activities that are being carried out when learning activities take place.

In learning activities, the teacher uses the question and answer method and assignment. The question and answer method is carried out for numbers card guessing activities. Furthermore, the method of assigning assignments is given for writing numbers based on the number of objects that have been counted by children, objects according to the theme (vehicle).

Furthermore, the teacher uses the question and answer method and converse in the activity of watching numbers introduction animation videos for children's numeracy skills. The Question and Answer method is used by the teacher in the activity to review the numbers and objects along with the number of objects based on (size, shape, number) in the animated video. Furthermore, the method of conversations used by the teacher for activities to 
express children's experiences after watching animated videos on numbers recognition in children's numeracy skills.

Then the teacher uses the question and answer method and assignment method. The question and answer method is given by the teacher to the activities of children's numeracy skills from the benefits of vehicles "cars and buses". Furthermore, the method of assigning assignments is used by teachers on patterning activities from the lowest number to the largest number.

In order for the implementation of a good teaching and learning process the teacher must use learning media and there must be suitable methods given to the child. The method used by the teacher is adapted to the learning media that will be used with learning numeracy skills. Fadillah (2012: 161) states that the method is a method or system used in learning that aims to enable students to know, understand, use and master certain subject matter. As well as all planning and procedures as well as the steps of learning activities including the choice of the method of assessment to be carried out.

\section{Implementation of Numerical skill}

Based on observations in Bungo Pasang Padang Aisyiyah 27 Kindergarten, in the implementation of children's numeracy skills learning, teachers use a variety of media, namely using visual media and audio-visual media.

Learning activities in class B2 preparation centers, teachers use numeric card media, picture cards that have numbers based on the number of images and stationery. The activities carried out are recognizing numbers by playing numbers guessing cards in accordance with the number of images on the pictorial number card and writing numbers based on the number of images.

The media used by the teacher is audio-visual media, namely the introduction of animated numbers for children's numeracy skills. In watching numbers recognition animation videos, children are invited to recognize numbers and vehicles "cars and buses" from the videos they watch. After watching the animated video, the teacher invited the child to ask questions about the numbers and how many vehicles (cars and buses) contained in the video.

The teacher uses visual media in the form of cars and buses made of cardboard with numbers and numbers in each car and bus. The teacher explains the uses, number of cars and buses, and then the teacher asks the child to sort the cars and buses according to the number sequence.

Based on the description above, it can be concluded that the implementation of learning activities on numeracy skills of children in Aisyiyah 27 Bungo Pasang Padang Kindergarten, is in accordance with the previously designed RPPH, in the use of methods the teacher has used various methods such as the question and answer method, conversation, and giving task. While the media used are visual and audio visual media. Visual media used are number cards and picture cards that have numbers, stationery, and cars and buses made of cardboard, in each car and bus there are numbers. While the audio-visual media used are animated numbers recognition videos for children's numeracy skills. Then the activities carried out by the teacher are also very interesting for the child so that the child is focused and very happy in participating in numeracy skills learning activities.

\section{Assessment}

Based on the results of observations and interviews conducted by researchers in the implementation of numeracy skills learning activities in Aisyiyah 27 kindergarten Bungo Pasang Padang, the teacher has conducted a learning evaluation to find out where the child's knowledge about counting.

Teacher evaluation is carried out by direct observation of children. The teacher conducts an evaluation when the learning activities take place, the teacher pays attention to which children can work on their own activities. With the teacher accompanying the child to work on the learning activities, the teacher will get the evaluation results.

The teacher also sees the development of the child for performance during the activity, during the learning process the teacher can assess the child who can take part in the activity well and what is not, so that the teacher can directly guide the child who still needs teacher assistance in the activities given by the teacher.

In addition, the teacher also evaluates every aspect of a child's development, starting from the child coming to the child going home from school, the assessment is done by observing with anecdotal notes techniques and checklist lists.

\section{DISCUSSION}

Based on the research that has been done by the researcher, the researcher will describe the discussion of the data that has been obtained. The research results that have been obtained will be used to obtain the expected results. Then it is relevant to the relevance associated with the discussion. The discussion is as follows:

A. Implementation Design of Children's Numerical Skill Thought Learning Activity

Findings obtained from observations and interviews conducted by researchers about planning children's numeracy learning activities in accordance with existing procedures, namely starting from Semester Program, Weekly Learning Implementation Plan (RPPM), and Daily Learning Implementation Plan (RPPH). In line with the opinion of Mareta (2015: 3) three types of learning planning that must be prepared and prepared by the teacher before implementing learning, namely, Semester Program, Weekly Learning Implementation Plan and Daily Learning Implementation Plan. The Semester Program is designed according to the existing curriculum. The semester program is a learning design that contains a theme network, the field of development, the level of achievement of development, indicators arranged in a sequence and systematically, the allocation of time needed for each network theme and its distribution into each semester.

Based on the findings of observations and interviews in class B2 about the planning of learning activities the development of numeracy skills conducted by the teacher has been going well, starting from the semester program, 
RPPM and RPPH. Can be seen in the planning of learning activities of numeracy skills by the teacher, namely the teacher makes daily planning. In planning the use of learning media, numeracy skills of teachers design activities using visual and audio-visual media, such as numeric cards, stationery, picture cards with numbers, cars and buses made of cardboard with numbers and animated videos for children's numeracy skills.

\section{B. Learning Method of Numerical Skill}

Based on the findings of observations and interviews in class B2 in Bungy Pasang Padang Aisyiyah 27 Kindergarten, the methods used by teachers in numeracy learning activities are the question and answer method to explore children's knowledge, conversation methods, and assignment of tasks.

This is in line with Hildebrand's opinion in Moeslichatoen (2004: 31) as for the kinds of methods that can be used to develop aspects of child development in the preparation center, namely the method of giving assignments, question and answer, and conversing.

C. Implementation of Learning Numerical Skill

During the learning of numeracy skills in Aisyiyah 27 kindergarten Bungo Put on the field, the teacher carried out activities in accordance with the plans that had been made previously. Implementation is the implementation of the design of the implementation of learning.

The implementation of learning in kindergarten in addition to planning, media is also very necessary, teaching methods and strategies must also be appropriate because learning in kindergarten is delivered by playing while learning, learning while playing. Therefore, the chosen media must be in accordance with the activities and provide a beneficial experience for the child. The teacher must also prepare how the activities will be carried out.

D. Form of Assessment of Learning Activities in Numerical Skill

The form of assessment carried out by the teacher in learning activities on numeracy skills in Bungo Post Aisyiyah 27 Kindergarten, including in the form of child work sheets or portfolios, check list lists, observations and observations of performance from the initial activities to the final activities. In line with the opinion of Suminah (2015: 5) said that in carrying out observations in the assessment the teacher recorded as evidence as well as a reminder of everything he observed.

The research findings obtained from the results of observations and interviews conducted by researchers about the form of assessment of learning numeracy skills adapted to the form of activity. Observation as a daily activity journal that observes children's activities during daily learning activities.

Then the teacher evaluates the learning of numeracy skills using a check list, the teacher makes a checklist when the learning activities are completed and the assessment is based on the indicators set in the learning plan. The teacher assesses using 4 scales, namely BB (Not Developing), MB (Starting to develop), BSH (Developing according to Expectations), BSB (Developing Very Well).
Assessment of learning numeracy skills is adjusted to the form of action, if the form of activity is in the form of assignments on the work sheet of the child, the teacher will evaluate the work of the child by giving initials, and thumbs up. For children who can do their work well get a thumbprint 4 , for children who can do their work but still ask for help from the teacher will get a thumbprint 3 and children who have been assisted by the teacher but cannot get a thumbprint.

The teacher also sees the development of counting children through performance during the activity, during the learning process the teacher can assess the child who can take part in the activity well and what is not, so the teacher can directly guide and direct the child who still needs teacher assistance. The teacher also evaluates every aspect of a child's development, starting from the child coming to school until the child comes home from school.

\section{CONCLUSION}

Based on research conducted in Bungo Pasang Padang Aisyiyah 27 Kindergarten, it can be concluded that the results of this study are, planning activities carried out by teachers in learning activities in the form of numerical skills in the form of RPPH before the activities take place and planned activities using varied media and interesting for children so that children do not feel bored in the process of learning activities.

The use of numeracy skills learning methods is carried out in accordance with activities and according to aspects of child development. The methods used are the question and answer method, the conversation method and the assignment method.

The use of numeracy skills learning media in Aisyiyah 27 Bungo Pasang Padang Kindergarten uses various media, namely using visual and audio-visual media. Thus the learning objectives of the desired numeracy skills can be achieved well.

The teacher conducts an assessment to find out the level of development of the child's numeracy skills carried out by observation, recording techniques (anecdotal notes) carried out to record all the facts experienced by the child that occur during the learning process, a check list is used to assess what indicators have developed in children and observing performance from the initial activities to the final activities in accordance with the form of activities provided.

\section{REFERENCES}

[1] Fadlillah, Muhammad. 2012. Desain Pembelajaran Paud. Jogyjakarta: Ar-Ruzz Media.

[2] Kemendikbud. 2014. Materi Pelatihan Guru Implementasi Kurikulum 2013 Tahun 2014. Pusat Pengembangan Profesi Pendidik.

[3] Moloeng, Lexy. 2012. Metodelogi Penelitian Kualitatif Edisi Revisi. Bandung: Remaja Rosdakarya. 
[4] Moeslichatoen.2004. Metode Pengajaran di Taman Kanak-kanak. Jakarta: PT Rineka CIPTA.

[5] Suryana, Dadan. Pengetahuan Tentang Strategi Pembelajaran, Sikap, Dan MotivasiGuru. Jurnal Ilmu Pendidikan, Jilid 19, Nomor2, Desember2013, H1m.196201

[6] Suryana, Dadan. 2017. Pembelajaran Tematik Terpadu Berbasis Pendekatan Saintifik Di ataman kanak-kanak. JURNAL PENDIDIKAN USIA DINI. Volume 11 Edisi 1, April 2017.

[7] Suryana, Dadan, 2017. Matematical learning model based on scientific approach in preschool.

[8] Suryana, Dadan. 2018. Stimulasi \& Aspek Perkembangan Anak. Jakarta PRENADAMEDIA GROUP.

[9] Susanto, Ahmad. 2011. Perkembangan Anak Usia Dini. jakarta: KENCANA PRENADAMEDIA GROUP.

[10] Sugiyono. 2009. Metode Penelitian Kuantitatif, Kualitatif dan $R \& D$. Bandung: Alfabeta

[11] Suminah, Mareta. 2015, Pedoman Implementasi Kurikulum 2013 PAUD, Jakarta: Direktorat Pembinaan Pendidikan Anak Usia Dini 